\title{
Developing sustainable school guidelines: the case of Egypt
}

\author{
$S$ Harb $^{1^{*}}, S$ M ElHaggar ${ }^{2}$, H Sewilam $^{3}$ \\ ${ }^{1}$ Research Assistant, American University in Cairo, Egypt, \\ ${ }^{2}$ Professor of Energy and Sustainable Development, American University in Cairo, Egypt \\ ${ }^{3}$ Professor and Director for Sustainable Development, American University in Cairo, Egypt
}

\begin{abstract}
Educational reform has been a concerning matter to the Egyptian government since the 20th century. In order to address the educational problems, several initiatives have instigated a quantitative expansion approach, rather than a qualitative one. Existing building assessment methods convey sustainability principles to building design. However, they do not consider the school design as an active pedagogical tool for sustainable education and development. In addition they do not integrate other imperative parameters necessary for the effective learning and development of students. The developed guideline is divided into two school rating systems; new and existing. The guideline is further divided into three main sustainability categories: energy, water, and habitat. The directing parameters of the guideline are based on sustainable building assessment parameters, Egypt's pressing social, economic and environmental concerns, pedagogy of educational environments, students' social, psychological, and developmental needs, in order to develop a holistic framework.
\end{abstract}

\section{Introduction}

\subsection{The educational system in the Arab Republic of Egypt}

The educational system in the Arab Republic of Egypt is the largest in the Middle East and North Africa (MENA) region.[1] At the national level, the rapid growth of Egypt's population poses a serious challenge, and places additional burdens on the educational system. In 2017, Egypt's population reached 97.5 million. In 2016-2017, and among 138 countries, Egypt ranked 89 in the basic requirements of health and education index, and 112 in the higher education and training index.[2] While Egypt has made significant progress in past decades to improve citizens' access to basic education, there is still considerable room for improvement regarding the quality of the country's education system.

Educational reform has been a concerning matter to the Egyptian government since the early 1990s.[3] In order to address the educational problems, several initiatives have instigated a quantitative expansion approach, rather than a qualitative one, which would focus on the quality of educational spaces. This is reflected in overcrowded classrooms, multiple-shift schools, poor school infrastructure and facilities, ineffective curricula, teaching tools and methods, in addition to incompetent teachers and school administrators.[4] It thus comes as no surprise that the World Economic Forum classifies Egypt as one of the countries with the lowest quality of basic education. Egypt ranks 100 out of 137 in the global competitiveness index.[5] However, data indicates that Egypt's public expenditure on education is high compared to countries of a similar national income. This attests that the challenges facing Egypt's educational system are in fact a result of ineffective and inefficient spending, rather than a shortage of resources.[1]

Similarly, literature has shown that the infrastructure of school buildings is both underserved and inefficient.[1] Unfortunately, the infrastructure of school buildings is partly responsible for creating either a positive or a negative educational environment. Despite its important role for the educational process, educational infrastructure has been overlooked and given the least priority within the educational reform plans. The number of hours and years consumed within educational facilities should be sufficient to explore the physical environment's influence on children's educational attainment and behavior.[6]

\subsection{Importance of education for sustainable development}

International organizations have underlined the significant role that public awareness, training, and education have in achieving sustainable development.[7] Dr. Mostafa Tolba, the Director of the United Nations Environment Programme stressed the importance of incorporating environmental education in schools as an imperative approach to face environmental challenges.[8] There was a prevalent adoption of environmental education in school systems globally, which included the development of curriculum and educational materials and the revision of syllabi to introduce the environmental

* Corresponding author: saraharb@aucegypt.edu 
aspect. Unfortunately, as critical voices have pointed out, the objectives of critical thinking, ethical obligation, active citizenship, and well-versed understanding called for by the Tbilisi conference were ignored by educators, until they were progressively removed from the curriculum. However, in the 1990s as the concern for poverty reduction raised more attention, a 'second wave' of environmental education emerged. This was discussed in the Agenda 21 report, in chapter 36 of the 1992 United Nations Conference on Environment and Development (UNCED), the Earth Summit, which discussed the pivotal role environmental education plays in sustainability.[9] During the 1990s, environmental education was superseded by education for sustainable development (ESD). It is based on the same principles; however, its focal concern is diverting education towards sustainable development, instead of just environmental sustainability. It denotes the power education holds in altering student's behavior by preparing them to be responsible individuals capable of supporting a sustainable future.[9] In 1996, The Commission on Sustainable Development (CSD), established by the United Nations to supervise the decisions of the UNCED, declared the importance of education for sustainable development as a means to amend the patterns of unsustainable consumption and production.[10] In December 2002, the United Nations General Assembly launched the 'Decade of Education for Sustainable Development', from 2005 to 2014. The implementation of the goals defined for this decade demands the efforts and cooperation of governments, international organizations, educational institutes, associations, communities, private sectors and citizens.

In the ESD Toolkit, the UNESCO states the difficulty for communities to integrate all of the aspects discussed in Agenda 21, UN conferences and major conventions within a single ESD curriculum. Therefore, they should selectively choose the environmental, social, or economic aspects issues to include based on the local relevance within the community.[7] Researchers conclude that educational reform in a country is subsequently linked with the curriculum, teacher's educational methods, local educational goals and governance, availability of contemporary teaching methods, and the educational built environment.[11] As previously reasoned, the built environment also plays a significant role in the way education shapes the school environment, and contirbutes to the sustainability of education. Sustainable schools are not only based on a design that saves energy and uses enviornmentally friendly materials, but they are also designed for students to learn in healthy, comfortable and postive school environments that teach sustainable practices. As Gough claims, a “... sustainable school is a most appropriate strategy for renovating educational processes and achieving quality education".[12]

\subsection{Relationship between architecture, education and society}

Sustainable built environments for education are not only a prerequisite for sustainable development, but also shape the formation of citizens and society more broadly. Thus, the design of educational spaces plays an important role in the formation of a sustainable culture. Papanek claims that "[a]11 design is education of a sort. It may be education by studying or teaching at a school or university, or it may be education through design".[13] It is therefore essential to understand that the student's learning experience is influenced by much more than the curriculum.[13-14] Rohwedder considers the school buildings as a 'pedagogy of place'. Therefore, an educational campus could be considered to consist of both a "built enviorment" which includes buildings and landscapes, and a "learning environment" comprised of students, faculty, and classrooms; in which the relationship between both environments is pedagogic.[15]

The main objective of educational systems is to maintain individual and societal improvement within the community through both tangible and moral extents. Therefore, the importance of educational facilities lies in their role in preventing the downfall of social and economic conditions within the community.[16] The school building design and operation should be an expression of the ongoing search for solutions to the rising number of local and global challenges. The construction, operational and planinng aspects of the campus should be mainfested in the school design. From this perspective, the campus would be congruous with the notion of sustainability. Inefficient structures constructed from energyintensive materials and run on fossil fuels give off the impression that energy is cheap, the environment is not to be safeguarded, and natural resources are abundant. Similarily, the operation of a school campus reflects the philosphy of education that drives educational policy and practice: "In this way, our educational institutions teach us how we should act".[15] David Orr highlights this pedagogical role in his claim:[17]

"It is paradoxical that buildings on college and university campuses, places of intellect, characteristically show so little thought, imagination, sense of place, ecological awareness, and relation to any larger pedagogical intent."

\subsection{The importance of sustainable schools}

Globally, building construction and operation account for $40 \%$ of the world's energy usage, $30 \%$ of raw material consumption, $16 \%$ of fresh water removal, $35 \%$ of carbon dioxide emissions, $55 \%$ of 
harvested timber, and $40 \%$ of the municipal solid waste production, which is ultimately sent to landfills. These impacts are detrimental, since buildings have a long-life cycle, and once a building is operational, its environmental footprint is not easily altered.[18] In addition, the Energy Information Administration forecasts reveal that the energy usage in buildings is estimated to increase by $32 \%$ between 2015 and 2040.[19] In recognition of these impacts, there has been a significant development of diverse schemes to incorporate environmentally friendly materials and technology in the construction sector; which brings about the notion of green design and sustainable design.[20]

Throughout the literature, the expressions 'green' and 'sustainable' are used conversely. This interchangeable use of terms has led to some confusion as to how green school designs are defined as opposed to sustainable school designs. Olson and Kellum state that "[s]ustainable schools, also referred to as green or high perfromance schools(...)".[21] Green buildings are defined by Earthman as mechanisms which conserve energy and water, and are constructed from environmentally-friendly materials.[22] Fenner\& Ryce underline the environmental aspect too, by reflecting upon green buildings as:[20]

“... structures that incorporate environmentally sensitive features and technologies from the initial design phase; they seek to meet or exceed resource and energy consumption targets that are set well above local requirements while taking into account the whole life cycle impact of the structure."

Hence, green schools could be defined as having a strictly environmental focus, whereas sustainable schools are concerned with the impact of the school building on the three pillars of sustainability. To contribute to the clarity of the proposed discussion, since green design is involved with the environmental impact of the school building, it could be considered to be just a subset of sustainable design.[23] Appropriately, a sustainable school has been described by Jensen to entail a whole system strategic approach that includes an understanding of the social, economic and environmental aspects, which should be addressed through the school design. A whole system approach also implies that sustainable schools require a holistic modfiication of the schools curriculum, teaching, operations, management of resrouces (i.e. water, energy, waste), and school's internal and external relationships, in order to transition the school towards sustainability.[24] This entails the translation of sustainability principles, such as equity, deference, and democracy into the school curriculum through pedagogical practices, which will have an impact on the students' learning and engagement.[25]

\subsection{Overview of existing sustainable school rating systems}

Building assessment methods were introduced as environmental issues become more urgent, and in recognition of the building and construction industries' accountability towards global energy usage, raw material consumption, fresh water removal, carbon dioxide emissions, harvested timber, and municipal solid waste production.[18] Since their introduction in the 1990s, building rating systems have emphasized the importance of green building practice, and have increased the awareness of environmental issues.[20] Similarly, the increased concern in school sustainability has led to the creation of various school sustainability rating systems, such as among others, Cyprus's and Canada's EcoSchool program, Ireland's Green-Schools program and the UK's LEED for Schools.[26] However, there is no rating system for sustainable schools in Egypt. Sustainable rating systems for schools could provide a multitude of benefits including: [26]

- help schools assess their existing sustainability performance, set goals, and measure the achieved progress towards attaining those goals;

- develop a shared langauge for school sustainability which enables schools to collaborate together and share knowledge;

- assist decision-makers in prioritizing sustainability efforts and accelerate the process of identifying potential areas for improvement;

- encourage the usage of the school campus as a teaching tool;

- allow schools to deliver their sustainability initiatives to stakeholders in a credible manner;

- recognize and reward schools for their sustainability efforts, and provide incentives for constant development.

While a range of sustainable assessment tools and frameworks for schools are available, little research exists on the extent to which they actually realize these potential benefits. In addition current rating systems are intended for use in a specific region, which does not allow its adaptability and limits their utility for knowledge-sharing and benchmarking with schools outside the intended region. Additionally, research indicates that most sustainability rating systems have weak or no accountability instruments, criteria with an emphasis on schemes rather than performance, replicated effort within the school sustainability community, and a marginal level of public reporting.[26]

\section{Developed sustainable design guidelines for new and existing schools in Egypt}

\subsection{Credit categories and divisions}

The developed guideline is divided into two main rating systems; new and existing schools. The guideline is further divided into three main sustainability categories: energy, water, and habitat, as illustrated in Table 1-5. 
Whereas the habitat category is further divided into three sub-categories: indoor environmental quality, materials and sustainable sites. The criteria governing the proposed guidelines are affordability, simplicity, and flexibility. The rating system for the developed guidelines are comprised of four levels: Bronze (40-49 points); Silver (50-59 points); Gold (60-69 points); Platinum (70+ points). New and existing buildings should satisfy minimum requirements for design and construction according to national building codes. Therefore, the guidelines do not replace the existing codes, but are considered a supplementary document which is only used to rate the educational built environment, and the operation of the facility from a sustainable perspective.

\subsection{Point allocation methodology}

Credit weights are tentative where the logic behind grading sustainability measures is based on the importance of the credit within the educational environment and the Egyptian context, based on practice and the available literature. Education and awareness program and innovation and creativity credits are given the largest weights given their pivotal role in an educational environment. Education is considered as an essential component of environmental awareness. Accordingly, through the five education and awareness programs the important connection between educational development and the sustainable learning environment is established. Such a connection is linked to the ability to transform fundamental knowledge into conscious action which empowers students to become ambassadors of sustainable development. The pivotal role of community collaboration in sustainable development is stressed upon by its allocation of numerous points across various credits; in order to broaden both the sustainable and scientific horizon of the community as a whole. Innovation and creativity credits are present within each of the three categories since creative solutions and notions are key components in our present knowledge-driven economy. Accordingly, the cultivation of creative learning and problem solving in the early school years allows students to develop higher order thinking processes which are required to create creative leaders in the future. It is not possible to do so without expanding beyond the conventional text-based learning approach and adopting more creative learning processes.

The philosophy behind the credit attainment process in new and existing schools is addressed in a way which considers the importance and ease or difficulty of credit attainment in both new schools and existing schools independently. In the sense that some credits are more difficult to achieve in existing schools than new schools, and some credits are more important to be achieved in existing schools than new schools. In the guidelines, in the case of Credit SS-03: Municipal Solid Waste Management, and Credit SS-04 Organic Waste Management, 4 and 3 points respectively were awarded for new schools, whereas 5 points were awarded for existing schools. This variation in credit weights was placed with the rationale that setting up a waste management system, and conducting waste audits in existing schools is more challenging than in new schools. In addition, in Credit SS08: Outdoor Playground Design, 3 and 5 points are allocated for new and existing schools respectively. Similarly, the justification in this case is that more planning efforts should be exerted in renovating the design an existing outdoor playground than creating an entirely new one, and it is more challenging to incorporate indoor classes with the outdoor spaces in existing schools than in new schools.

\section{Conclusions}

Existing building assessment methods provide a valuable method in conveying sustainability principles to building design. There is currently no rating system for schools in Egypt. Whereas existing international sustainable school rating systems do not account for the social and economic conditions within the building's direct context in the required way, which would contribute towards the sustainable development of the country. In addition, they do not integrate other imperative parameters necessary for the effective learning and development of students; such as the imperative role the school design plays as an active pedagogical tool for sustainable education and development. Sustainable schools should be considered as educational built environments in which the school building design and operations should be an expression of the ongoing search for solutions to the rising number of local and global challeges. Sustainable built environments for education are not only a prerequisite for sustainable development, but also shape the formation of citizens and society more broadly. Thus, the design of educational spaces plays an important role in the formation of a sustainable culture.

The guideline is based on cradle-to-cradle principles for the full utilization of all resources. The cradle-to-cradle concept adopts a cyclic flow of materials, which ensures that manufactured products are utilized, recovered, and reused while maintaining their high value throughout their lifecycle stages. In addition, the closed loop process of material flow reduces the environmental impacts associated with waste generation. The guidelines also seek to portray the role as agents of socio-economic development, which is an added value for the government, schools and the community as whole.

The developed guideline is divided into two school rating systems; new and existing. The guideline is further divided into three main sustainability categories: energy, water, and habitat. The Habitat category is divided into three sub-categories, indoor environmental quality, materials and sustainable sites. The total possible points in the Energy category for new and existing schools is 30 and 26 points respectively; the possible points in the Water category for new and existing schools is 18 for each; the possible points in the Indoor Environmental Quality sub-category for new and existing schools is 12 for each, whereas the possible points in the Materials subcategory for new and existing schools is 6 for each, and the possible points in Sustainable Sites sub-category for new and existing schools is 34 and 37 respectively. 
Table 1. Energy category

\begin{tabular}{|l|c|c|c|c|}
\hline \multicolumn{2}{|l}{} & $\begin{array}{c}\text { New } \\
\text { Schools }\end{array}$ & $\begin{array}{c}\text { Existing } \\
\text { Schools }\end{array}$ \\
\hline Prerequisite & E-01 & Energy Management Plan & Required & Required \\
\hline Prerequisite & E-02 & Commissioning & Required & N/A \\
\hline Credit & E-03 & On-Site Renewable Energy & 3 & 3 \\
\hline Credit & E-04 & Energy Metering & 2 & 2 \\
\hline Credit & E-05 & External Shading Devices & 2 & 2 \\
\hline Credit & E-06 & Building Controls Systems & 2 & 2 \\
\hline Credit & E-07 & External Wall Insulation & 4 & N/A \\
\hline Credit & E-08 & Roof Insulation & 1 & N/A \\
\hline Credit & E-09 & High Performance Windows and Glazing & 1 & N/A \\
\hline Credit & E-10 & Window-Wall Ratio & 1 & 1 \\
\hline Credit & E-11 & Reflective Wall Coatings & 2 & 2 \\
\hline Credit & E-12 & Air Tightness & 1 & 1 \\
\hline Credit & E-13 & Energy Efficient Lighting & 2 & 2 \\
\hline Credit & E-14 & Pump Motor Efficiency & 6 & 6 \\
\hline Credit & E-15 & Energy Efficient HVAC Systems & 30 & 26 \\
\hline Credit & E-16 & Innovation and Creativity in Energy & & 1 \\
\hline Possible points & & & & 2 \\
\hline
\end{tabular}

Table 2. Water category

\begin{tabular}{|l|c|c|c|c|}
\hline \multicolumn{2}{|l|}{} & $\begin{array}{c}\text { New } \\
\text { Schools }\end{array}$ & $\begin{array}{c}\text { Existing } \\
\text { Schools }\end{array}$ \\
\hline Prerequisite & W-01 & $\begin{array}{c}\text { Integrated Water and Wastewater Management } \\
\text { Plan }\end{array}$ & Required & Required \\
\hline Credit & W-02 & Water Saving Devices & 3 & 3 \\
\hline Credit & W-03 & Water Metering & 1 & 1 \\
\hline Credit & W-04 & Water Efficient Landscaping & 3 & 3 \\
\hline Credit & W-05 & Treatment and Reuse of Greywater & 3 & 3 \\
\hline Credit & W-06 & Rain Water and AC Condensate Harvesting & 2 & 2 \\
\hline Credit & W-07 & Innovation and Creativity in Water & 6 & 6 \\
\hline Possible points & & 18 & 18 \\
\hline
\end{tabular}

Table 3. Habitat Category: Indoor Environmental Quality

\begin{tabular}{|l|c|c|c|c|}
\hline \multicolumn{2}{|l|}{} & $\begin{array}{c}\text { New } \\
\text { Schools }\end{array}$ & $\begin{array}{c}\text { Existing } \\
\text { Schools }\end{array}$ \\
\hline Prerequisite & IEQ-01 & $\begin{array}{c}\text { Environmental Tobacco Smoke (ETS) Control } \\
\text { Plan }\end{array}$ & Required & Required \\
\hline Credit & IEQ-02 & Construction Activity Pollution Prevention Plan & Required & N/A \\
\hline Credit & IEQ-03 & Acoustical Performance & 3 & 3 \\
\hline Credit & IEQ-04 & Indoor Chemical and Pollutant Source Control & 1 & 1 \\
\hline Credit & IEQ-05 & Natural Ventilation & 3 & 3 \\
\hline Credit & IEQ-06 & Daylight & 2 & 2 \\
\hline Credit & IEQ-07 & Effective Seating Arrangements & 1 & 1 \\
\hline & IEQ-08 & Psychology of Color in the Educational \\
Credit & Environment & 2 & 2 \\
\hline \multicolumn{2}{l|}{ Possible points } & 12 & 12 \\
\hline
\end{tabular}

Table 4. Habitat Category: Materials

\begin{tabular}{|c|c|c|c|c|}
\hline & & & $\begin{array}{c}\text { New } \\
\text { Schools }\end{array}$ & $\begin{array}{l}\text { Existing } \\
\text { Schools }\end{array}$ \\
\hline Credit & MAT-01 & Local Materials & 3 & 3 \\
\hline Credit & MAT-02 & Low VOC Materials & 3 & 3 \\
\hline \multicolumn{3}{|c|}{ Possible points } & 6 & 6 \\
\hline
\end{tabular}


Table 5. Habitat Category: Sustainable Sites

\begin{tabular}{|l|c|c|c|c|}
\hline \multicolumn{2}{|l}{} & $\begin{array}{c}\text { New } \\
\text { Schools }\end{array}$ & $\begin{array}{c}\text { Existing } \\
\text { Schools }\end{array}$ \\
\hline Prerequisite & SS-01 & Integrated Solid Waste Management Plan & Required & Required \\
\hline Credit & SS-02 & Construction Waste Management & 3 & N/A \\
\hline Credit & SS-03 & Municipal Solid Waste Management & 4 & 5 \\
\hline Credit & SS-04 & Organic Waste Management & 3 & 5 \\
\hline Credit & SS-05 & Design for People with Special Educational Needs & 1 & 1 \\
\hline Credit & SS-06 & Protect and/or Restore Existing Trees & 1 & N/A \\
\hline Credit & SS-07 & Outdoor Playground Design & 3 & 5 \\
\hline Credit & SS-08 & School Building Orientation & 2 & N/A \\
\hline Credit & SS-09 & Safety and Security & 2 & 2 \\
\hline Credit & SS-10 & Sustainability Expert & 3 & 3 \\
\hline Credit & SS-11 & Education \& Awareness Program & 6 & 6 \\
\hline Credit & SS-12 & Preventive and Corrective Maintenance & N/A & 4 \\
\hline Credit & SS-13 & Innovation and Creativity in Habitat & 6 & 6 \\
\hline Possible points & & & 34 & 37 \\
\hline
\end{tabular}

The criteria governing the proposed guidelines are affordability, simplicity, and flexibility. The rating system for the developed guidelines are comprised of four levels: Bronze (40-49 points); Silver (50-59 points); Gold (60-69 points); Platinum (70+ points). The directing parameters of the guideline are based on sustainable building assessment guidelines, Egypt's pressing social, economic and environmental concerns, pedagogy of educational environments, students' social, psychological, and developmental needs, in order to develop a holistic framework. Education and awareness program and innovation and creativity credits are given the largest weights given their pivotal role in an educational environment. Similarly, the pivotal role of community collaboration in sustainable development is stressed upon by its allocation of numerous points across various credits; in order to broaden both the sustainable and scientific horizon of the community as a whole. Innovation and creativity credits are present within each of the three categories since creative solutions and notions are key components in our present knowledge-driven economy.

\section{References}

1. The World Bank. (2005). Policy Note 2: Making egyptian education spending more effective: Egypt Public Expenditure Review. Washington: Social and Economic Development Group Middle East and North Africa Region.

2. CAPMAS. (2017, December 26). Central Agency for Public Mobilization and Statistics. Retrieved December 26, 2017, from http://www.capmas.gov.eg/

3. El Baradei, M., \& El Baradei, L. (2004). Needs Assessment of the Education Sector in Egypt .
4. Ministry of Education. (2014). Strategic Plan for Pre-University Education 2014-2030.

5. World Economic Forum. (2017). The Global Competitiveness Index 2017-2018 edition.

6. [6] Clark, H. (2002). Building Education: The role of the physical environment in enhancing teaching and research. London: Institute of Education, Universty of London.

7. UNESCO. (2006). Education for Sustainable Development Toolkit . Paris: UNESCO.

8. UNESCO. (1977). Intergovernmental Conference on Environmental Education: Tbilisi (USSE). UNESCO.

9. UNCED. (1992). Agenda 21. Rio de Janerio, Brazil.

10. UNESCO-UNEP. (1996). Connect: The UNESCO-UNEP environmental education newsletter.

11. Brković, M., \& Milošević , P. (2012). Sustainable Schools as 3D Textbooks: Safeguards of Environmental Sustainability. Architecture and Civil Engineering, 10(2), 179191.

12. Gough, A. (2005). Sustainable Schools: Renovating Educational Processes . Applied Environmental Education \& Communication Volume 4, 2005 - Issue 4, 4, 339-351.

13. Papanek, V. (2009). Design for the Real World: Human Ecology and Social Change. Chicago: Academy Chicago Publishers.

14. Elseragy, A., Gabr, M., \& Elnokaly, A. (2011). Building Sustainable Learning Environments that are 'Fit for the Future' with Reference to 
Egypt. World Sustainable Building Conference, 2, pp. 456-462. Helsinki.

15. Rohwedder, R. (2004). Pedagogy of Place: The Environmental Technology Center at Sonoma State University. In P. B. Corcoran, \& A. E. Wals (Eds.), Higher Education and the Challenge of Sustainability: Problematics, Promise and Practice (pp. 293-304). Kluwer Academic Publishers.

16. Türkkahraman, M. (2012). Journal of education and instructional studies in the world, 2(4), 3841.

17. Orr, D. W. (1993). Architecture as Pedagogy. Society for Conservation Biology, 7, 226-228.

18. Roodman , D. M., \& Lenssen, N. (1995). A Building Revolution: How Ecology and Health Concerns Are Transforming Construction. Washington, DC: Worldwatch Institute.

19. Energy Information Adminstration. (2017). International Energy Outlook 2017. Washington, DC: US Department of Energy.

20. Fenner, R. A., \& Ryce, T. (2008). A comparative analysis of two building rating systems. Part 1: Evaluation. Engineering Sustainability, 6, 55-63.

21. Olson, S. L., \& Kellum, S. (2003). The Impact of Sustainable Buildings on Educational Achievements in K-12 Schools. Wisconsin:
Leonardo Academy Cleaner and Greener Program Report.

22. BIBLIOGRAPHY Earthman, G. I. (2009). Planning Educational Facilities. Rowman and Littlefield Education.

23. Lippman, P. C. (2010). Evidence-based design of Elementary and Secondary Schools. Hoboken: John Wiley \& Sons, Inc.

24. Jensen, B. B. (2005). Building Capacity and Empowerment through ESD. Vienna: Austrian Federal Ministry of Education, Science and Culture

25. Kadji-Beltran, C., Zachariou, A., \& Stevenson, R. B. (2013). Leading sustainable schools: exploring the role of primary school principals. Environmental Education Research , 19(3), 303-323.

26. Dautremont-Smith, J. (2012). School Sustainability Rating Systems: Strengths, Limitations, and Future Prospects . Michigan: Unpublished Master's Thesis, University of Michigan. 